\title{
Synthesis of Novel Halobenzyloxy and Alkoxy 1,2,4-Triazoles and Evaluation for Their Antifungal and Antibacterial Activities
}

\author{
Kun Wan and Cheng-He Zhou* \\ Laboratory of Bioorganic \& Medicinal Chemistry, School of Chemistry and Chemical Engineering, Southwest University, \\ Chongqing 400715, P. R. China.*E-mail: zhouch@swu.edu.cn \\ Received March 2, 2010, Accepted May 25, 2010
}

\begin{abstract}
A new class of halobenzyloxy or alkoxy 1,2,4-triazoles and their hydrochlorides were synthesized through cyclization starting from commercially available phenylhydrazine. The structures were characterized by MS, IR and ${ }^{1} \mathrm{H}$ NMR spectra as well as elemental analyses. All the synthesized compounds were screened for their antibacterial activities in vitro against Staphylococcus aureus (ATCC29213), methicillin-resistant Staphylococcus aureus (N315), Bacillus subtilis, Escherichia coli (ATCC25922), Pseudomonas aeruginosa, Shigella dysenteriae, Eberthella typhosa, and antifungal activities against Candida albicans (ATCC76615), Aspergillus fumigatus by broth microdilution assay method. The results of preliminary bioassay indicated that 3-(2,4-difluorobenzyloxy)-1-phenyl-1H-1,2,4-triazole hydrochloride exhibited the best inhibitory activity with an MIC value of $56.25 \mu \mathrm{M}$ against $P$. aeruginosa superior to Chloramphenicol, and showed comparable activity with Chloramphenicol against E. coli (ATCC25922).
\end{abstract}

Key Words: 1,2,4-Triazole, Cyclization, Phenylhydrazine, Antifungal, Antibacterial

\section{Introduction}

The incidence of systemic fungal infections such as candidosis, cryptococcosis, and aspergillosis has been rapidly increasing mainly due to the growing number of immunocompromised hosts in the past few decades. Similarly, the dramatically rising prevalence of multi-drug resistant microbial infections has recently become a serious health care problem. Particularly, the emergence of multi-drug-resistant Gram-positive bacteria including methicillin-resistant Staphylococcus aureus (MRSA) and vancomycin-resistant Enterococci (VRE) has been a problem of ever-increasing significance in both community and hospital acquired infections. ${ }^{1}$ Thus, there is a real perceived need for the discovery of new compounds with high efficiency, broad spectrum and low toxicity, which are structurally distinct from those of well known classes of antimicrobial agents to which many clinically relevant pathogens are now resistant. Consequently, the search for new molecular scaffolds will always remain an important and challenging task for medicinal chemists.

Azole compounds especially 1,2,4-triazole derivatives are quite important types of nitrogen-containing aromatic heterocyclic compounds endowed with excellent safety profile, favorable pharmacokinetic characteristics and wide biological activities. ${ }^{2-9}$ Noticeably, 1,2,4-triazoles as antimicrobial agents have aroused special attention in medicinal chemistry in recent years due to their prominent activity, low toxicity as well as broad spectrum. ${ }^{10}$ So far a large number of 1,2,4-triazole antimicrobial compounds have been extensively used in clinic. ${ }^{11}$ For example, Fluconazole shows good antifungal activity with relatively low toxicity and has been preferred as first-line antifungal therapy. ${ }^{12}$ However, Fluconazole is not effective against invasive aspergillosis and has suffered severe drug resistance. Itraconazole is an improvement of Fluconazole in terms of having a broad antifungal spectrum and better toleration, whereas its use is hampered by variable oral absorption and low bioavailability. This si- tuation has led to an ongoing search for new azoles. Very recently, a substantial effort has been devoted to the modification and optimization of the existing triazole antimicriobial agents which relied on the empirical development of a structure-activity relationship (SAR). ${ }^{13}$ On the other hand, it is also an increasing prevalence of one such strategy that has been pursued in recent years to develop new antimicrobial agents with novel chemical structures, which could have modes of action rather than analogs of the existing ones.

In our ongoing interest in the development of new antimicrobial agents, ${ }^{14-18}$ our attention has been focusing on the discovery of novel $N$-substituted 1,2,4-triazole compounds with structurally difference from the well known ones via $\mathrm{N}$-alkylation of 1,2,4-triazole ring. ${ }^{14,15}$ Except that, there are still so many approaches that are available for the insertion of specific functionalities into the 1,2,4-triazole nucleus to build up diversified substituted 1,2,4-triazoles. ${ }^{19-25}$ The alterations in chemical structure of substituted 1,2,4-triazoles could affect their interactions with cells and tissues, thereby exhibiting different biological effects. Furthermore, much research manifested that incorporation of fluorine or chlorine moiety into an organic molecule could efficiently improve the pharmacological properties, ${ }^{26-29}$ which resulted in increasing lipid solubility, accordingly enhancing the rate of absorption and transport of drugs in vivo. The replacement of hydrogen or hydroxyl group by fluorine or chlorine represents a valuable strategy and was extensively used in drug development to alter biological function. ${ }^{30,31}$ Meanwhile, the introduction of alkyl moiety into various heterocyclic systems as the large non-polar portion could play an important role in modulating the physicochemical properties of the whole molecule that possibly avoid some side effects and improve their pharmacokinetic and pharmacodynamic behaviors. This is also helpful to increase their biological activities. ${ }^{32-34}$

On the basis of all above observations and as an extension of our studies on biologically active $N$-substituted 1,2,4-triazol- 
es derivatives, herein a series of novel halobenzyloxy and alkoxy 1,2,4-triazole compounds have been synthesized and evaluated for their antibacterial and antifungal activities in vitro. Additionally, their corresponding hydrochlorides were also prepared in order to investigate the effect of water solubility of target triazoles on the antimicrobial activities, and their structure-activity relationships were also discussed.

\section{Results and Discussion}

Chemistry. The synthetic route of halobenzyloxy or alkoxy 1,2,4-triazole derivatives 3-4 and their hydrochlorides 5-6 was outlined in Scheme 1. Phenylhydrazine 1 was first reacted with urea to give the intermediate phenylhydrazinecarboxamide, and then the later was cyclized with formic acid to afford the corresponding hydroxytriazole 2 . $^{35}$ The etherification of 1 phenyl-1,2,4-triazole-3-ol (2) using halogen-substituted benzyl or alkyl halides in the presence of anhydrous potassium carbonate and TBAI afforded halobenzyloxy or alkoxy 1,2,4-triazoles (3a-g, 4a-e) in moderate to excellent yields (from $56 \%$ to $89 \%$ ), and then treated in ethyl ether with $\mathrm{HCl}(4 \mathrm{~mol} / \mathrm{L})$ to give the corresponding hydrochlorides (5a-g, 6a-e) in high yields ranging from $81 \%$ to $88 \%$.

Experimental results revealed that the ratio of reactants, solvent, reaction time, amount of catalyst as well as the addition rate of concentration sulfuric acid exerted important influences on the yield of hydroxytriazole (2). Therefore, we optimized the cyclization conditions, and exploited an one-pot, three-component synthesis strategy to construct the 1,2,4-triazole ring, which represented an easy, convenient and efficient synthetic route.

The intermediate hydroxytriazole 2 involves two tautomeric forms. When it reacted with halogen-substituted benzyl or alkyl halides, it may be in the wake of obtaining the $\mathrm{N}$-alkylation products in the $O$-alkylation reaction. The $O$-alkylation reaction was found to be highly sensitive to reaction temperature, solvent and $\mathrm{pH}$. When the temperature was above $80^{\circ} \mathrm{C}$, the reaction became complex, and thus led to poor yields. However, too low temperature (below $55^{\circ} \mathrm{C}$ ) would not only greatly decrease the reactivity but also make the reaction sluggish enough to lower the yields. The optimal reaction temperature was at $70-75^{\circ} \mathrm{C}$ in our study, which gave the highest yields. Moreover, the reaction failed as the $\mathrm{pH}$ was higher than 10 or less than 6 . The results confirmed that the presence of weak base $\left(\mathrm{K}_{2} \mathrm{CO}_{3}\right)$ in acetonitrile at $70-75^{\circ} \mathrm{C}$ with pH $7.5-8.5$ was favorable to this $O$-alkylation reaction.

It was also noticed that the presence of the triazole hydrochloride in compounds 5-6 resulted in a better water solubility in comparison with the corresponding precursors 3-4, while alkoxy triazole hydrochlorides possessed better solubility than halobenzyloxy ones in other solvents such as chloroform, tetrahydrofuran and acetone.

Analysis of spectra. All the synthesized compounds were confirmed by MS, IR and ${ }^{1} \mathrm{H}$ NMR spectra as well as elemental analyses. The spectral analyses were in accordance with the assigned structures, and all the characterization data were given in the experimental section. The mass spectra for the target compounds showed a major fragment of $[\mathrm{M}]^{+},[\mathrm{M}+\mathrm{H}]^{+}$or $[\mathrm{M}-\mathrm{HCl}]^{+}$,

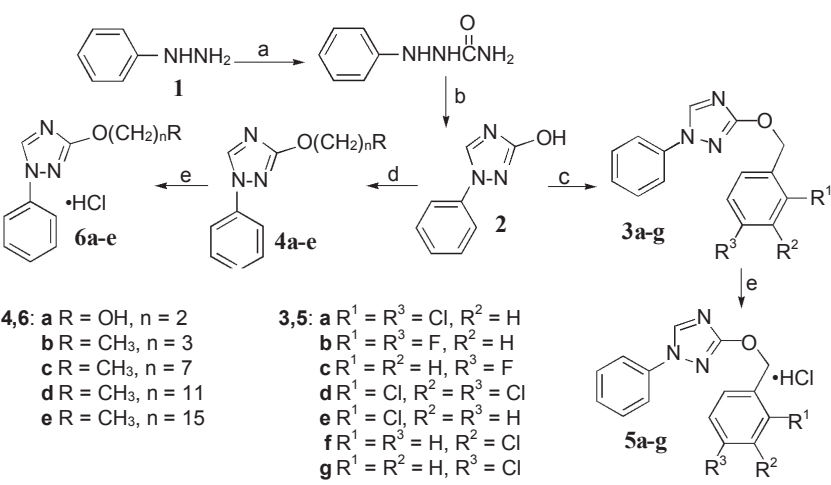

Scheme 1. Synthetic route of halobenzyloxy and alkoxy triazole derivatives 3-6. Reagents and conditions: (a) $\mathrm{NH}_{2} \mathrm{CONH}_{2} / \mathrm{H}_{2} \mathrm{SO}_{4} / \mathrm{H}_{2} \mathrm{O}$, $100{ }^{\circ} \mathrm{C}$; (b) $\mathrm{HCOOH} / \mathrm{H}_{2} \mathrm{SO}_{4}, 125^{\circ} \mathrm{C}$; (c) halobenzyl bromide or chloride, TBAI, $\mathrm{K}_{2} \mathrm{CO}_{3} / \mathrm{CH}_{3} \mathrm{CN}, 70{ }^{\circ} \mathrm{C}$; (d) $\mathrm{R}\left(\mathrm{CH}_{2}\right)_{\mathrm{n}} \mathrm{Br}$, TBAI, $\mathrm{K}_{2} \mathrm{CO}_{3} /$ $\mathrm{CH}_{3} \mathrm{CN}, 75^{\circ} \mathrm{C}$; (e) $4 \mathrm{~mol} / \mathrm{L} \mathrm{HCl} /$ ethyl ether, rt.

in agreement with their molecular formula.

IR spectra: The IR spectra of compounds 3-6 exhibited that one moderate and two characteristic strong absorption bands at $3200-3000 \mathrm{~cm}^{-1}, 1290-1200 \mathrm{~cm}^{-1}$ and $1110-1000 \mathrm{~cm}^{-1}$ were respectively attributable to the stretching vibration of $\mathrm{Ar}-\mathrm{H}$, the anti-symmetric stretching vibration and the symmetric stretching vibration of C-O-C bonds. Moreover, it was found that all the vibration frequency in halobenzyloxy or alkoxy 1,2,4-triazoles was obviously shifted to higher wave numbers in contrast to their corresponding hydrochlorides, which was mainly responsible for the inductive effects of the positive charges in triazole moiety. For another, the $\mathrm{H}_{2} \mathrm{C}-\mathrm{O}$ absorption bands in halobenzyloxy 1,2,4-triazoles were observed at higher frequency in comparison with that in alkoxy ones owing to the electrophilic inductive effects fluorine or chlorine moiety and conjugation effects of benzene ring in compounds $\mathbf{3 a - g}$ and $\mathbf{5 a - g}$.

${ }^{1}$ HNMR spectra: The ${ }^{1} \mathrm{H}$ NMR spectra showed that two singlets at the region of $5.62-4.34$ ppm and $8.95-7.84$ ppm were assigned to the methylene protons of alkoxy or halobenzyloxy group and the $\mathrm{N}=\mathrm{CH}$ protons of triazole ring in all title compounds respectively. Furthermore, the downfield shift of the methylene protons of the halobenzyl compounds was observed, in comparison with that in alkyl substituted 1,2,4-triazoles. In the ${ }^{1} \mathrm{H}$ NMR spectra, it was also found that all the triazole $\mathrm{N}=$ $\mathrm{CH}$ protons and the methylene protons in the hydrochlorides showed large downfield shifts compared to the corresponding precursors, probably ascribed to the presence of positive charges in the hydrochlorides. All the other aromatic and aliphatic protons appeared at the appropriate chemical shifts and integral values.

Biological activity. These halobenzyloxy and alkoxy 1,2,4triazoles 3-4 and their hydrochlorides 5-6 were evaluated for their antimicrobial activities against MRSA (N315), S. aureus (ATCC29213) and B. subtilis as Gram-positive, E. coli (ATCC25922), P. aeruginosa, S. dysenteriae and E. typhosa as Gramnegative bacteria, as well as $C$. albicans (ATCC76615) and $A$. fumigatus as fungi by broth microdilution assay method. Clinical antimicrobial drugs Chloramphenicol and Fluconazole were served as the positive control. The minimum inhibitory concentration (MIC, $\mu \mathrm{M})$ values were compiled in Table 1. 
Table 1. In vitro antibacterial and antifungal activities of the title compounds $3-6^{a, b, c, d}$

\begin{tabular}{|c|c|c|c|c|c|c|c|c|c|}
\hline \multicolumn{10}{|c|}{$\mathrm{MIC}_{\mu} \mathrm{M}^{d}$} \\
\hline \multicolumn{3}{|c|}{ Fungal strains } & \multicolumn{7}{|c|}{ Baterial strains } \\
\hline Compd. & C. albicans & A. fumigatus & S. aureus & B. subtilis & P. aeruginosa & E. coli & S. dysenteriae & $M R S A$ & E. typhosa \\
\hline $3 \mathbf{a}$ & 400 & 800 & 800 & $>1600$ & 800 & 1600 & 800 & 1600 & 800 \\
\hline $\mathbf{3 b}$ & 900 & 900 & 450 & 225 & 112.5 & 112.5 & 450 & 1800 & 450 \\
\hline $3 \mathrm{c}$ & 950 & $>1900$ & 950 & 1900 & 950 & 950 & $>1900$ & $>1900$ & 1900 \\
\hline 3d & $>1600$ & $>1600$ & $>1600$ & 1600 & 1600 & 1600 & $>1600$ & $>1600$ & $>1600$ \\
\hline $3 e$ & 1800 & 1800 & $>1800$ & 1800 & 1800 & 1800 & 1800 & $>1800$ & 900 \\
\hline $3 f$ & $>1800$ & 1800 & 1800 & 1800 & 1800 & 1800 & 900 & $>1800$ & 1800 \\
\hline $3 g$ & 1800 & 1800 & $>1800$ & 900 & 900 & 900 & 1800 & $>1800$ & 1800 \\
\hline $4 a$ & $>2500$ & $>2500$ & $>2500$ & $>2500$ & $>2500$ & $>2500$ & $>2500$ & $>2500$ & $>2500$ \\
\hline $4 b$ & $>2360$ & $>2360$ & $>2360$ & $>2360$ & $>2360$ & $>2360$ & $>2360$ & $>2360$ & $>2360$ \\
\hline $4 c$ & 1880 & 1880 & 1880 & 940 & 1880 & 940 & $>1880$ & $>1880$ & 470 \\
\hline $4 d$ & 780 & $>1560$ & 780 & 780 & 1560 & 390 & 1560 & $>1560$ & 1560 \\
\hline $4 e$ & $>1330$ & $>1330$ & $>1330$ & $>1330$ & $>1330$ & $>1330$ & $>1330$ & $>1330$ & $>1330$ \\
\hline $5 a$ & 200 & 800 & 400 & $>1600$ & 400 & 800 & 400 & 800 & 400 \\
\hline $5 b$ & 450 & 450 & 450 & 112.5 & 56.25 & 56.25 & 225 & 450 & 450 \\
\hline $5 c$ & 950 & $>1900$ & 950 & 950 & 475 & 475 & $>1900$ & $>1900$ & 950 \\
\hline $5 d$ & $>1600$ & $>1600$ & $>1600$ & 800 & 800 & 800 & $>1600$ & $>1600$ & $>1600$ \\
\hline $5 e$ & 900 & 900 & $>1800$ & 900 & $>1800$ & 450 & 900 & $>1800$ & 450 \\
\hline $5 f$ & 900 & 900 & 450 & 450 & 900 & 900 & 450 & $>1800$ & 900 \\
\hline $5 \mathrm{~g}$ & 900 & 900 & $>1800$ & 900 & 450 & 450 & 900 & $>1800$ & 900 \\
\hline $6 a$ & $>2500$ & $>2500$ & $>2500$ & $>2500$ & $>2500$ & $>2500$ & $>2500$ & $>2500$ & $>2500$ \\
\hline $6 b$ & $>2360$ & $>2360$ & $>2360$ & 2360 & 2360 & $>2360$ & $>2360$ & $>2360$ & 2360 \\
\hline $6 c$ & 940 & 940 & 940 & 235 & 470 & 470 & $>1880$ & $>1880$ & 235 \\
\hline $6 d$ & 390 & 1560 & 195 & 390 & 780 & 195 & 780 & 1560 & 780 \\
\hline $6 e$ & $>1330$ & $>1330$ & $>1330$ & 1330 & $>1330$ & 1330 & $>1330$ & $>1330$ & 665 \\
\hline $\mathbf{A}$ & - & - & 198.1 & $>1584$ & $>1584$ & 49.52 & 49.52 & 49.52 & 49.52 \\
\hline B & 52.24 & $>1671$ & - & - & - & - & - & - & - \\
\hline
\end{tabular}

${ }^{a}$ Minimum inhibitory concentrations were determined by micro broth dilution method for microdilution plates. ${ }^{b} \mathbf{A}=$ Chloramphenicol, $\mathbf{B}=$ Fluconazole. ${ }^{c}$ C. albicans, Candida albicans ATCC76615; A. fumigatus, Aspergillus fumigatus; S. aureus, Staphylococcus aureus ATCC29213, B. subtilis, Bacillus subtilis; E. coli, Escherichia coli ATCC25922; P. aeruginosa, Pseudomonas aeruginosa; S. dysenteriae, Shigella dysenteriae; MRSA, Methicillin-Resistant Staphylococcus aureus $\mathrm{N} 315$; E. typhosa, Eberthella typhosa. ${ }^{d} \mathrm{MIC}$ values was in $\mu \mathrm{M}$.

Antibacterial activity: The investigation of antibacterial screening data revealed that some target compounds exhibited significant inhibitory activities against some tested strains such as $B$. subtilis and $P$. aeruginosa at $56.25-475 \mu \mathrm{M}$ in vitro. Especially, it was worthy to note that the compounds $\mathbf{3} \mathbf{a}$ and $\mathbf{3 b}$ as well as their corresponding hydrochlorides $\mathbf{5} \mathbf{a}$ and $\mathbf{5} \mathbf{b}$ bearing 2,4-difluorobenzyloxy and 2,4-dichlorobenzyloxy groups exhibited the most prominent activity against all bacterial strains tested at the concentration of $56.25-450 \mu \mathrm{M}$, in comparison with other halobenzyloxy 1,2,4-triazoles, which was possibly attributed to the presence of pharmacologically active dihalophenyl moiety at position 3 of the triazole ring. That suggested that 2,4-dichlorobenzyl or 2,4-difluorobenzyl substitution in the triazole ring was suitable for antibacterial activity.

On basis of the bioactive data, it was observed that the antibacterial activities for alkoxy derivatives 4a-e and 6a-e were weaker in comparison to halobenzyloxy compounds $\mathbf{3 a - g}$ and 5a-g. However, compounds $\mathbf{4 c}, \mathbf{4 d}$ and their hydrochlorides $\mathbf{6 c}$, 6d containing long alkyl chains with lengths in the range of
C8-C12 gave significant activities against some tested strains with MIC values ranging from $195 \mu \mathrm{M}$ to $470 \mu \mathrm{M}$. Conversely, the antibacterial results showed no obvious inhibition for compounds $4 \mathbf{a}, 4 \mathbf{b}$ including their hydrochlorides $\mathbf{6 a}, \mathbf{6 b}$ with short $\mathrm{C} 2-\mathrm{C} 4$ alkyl chain. Therefore, the introduction of linear alkyl with lengths in the range of $\mathrm{C} 8-\mathrm{C} 12$ into 1,2,4-triazole ring could enhance antibacterial activities.

The 4-nitrogen of triaozle ring is liable to quaternary, and formed into quaternary ammonium salt, which is favourable to improve water-solubility and enhance activities. In vitro studies demonstrated that all the halobenzyloxy and alkoxy 1,2,4-triazole hydrochlorides 5-6 exhibited better activities compared to the corresponding precursors 3-4, in particular, compound $\mathbf{5 b}$ possessed dramatic biological activities against nearly all tested strains with MIC values ranging from $56.25 \mu \mathrm{M}$ to $450 \mu \mathrm{M}$, shown in Table 1. Noticeably, compound $\mathbf{5 b}$ gave 15 - 30 times higher potency than Chloramphenicol against $B$. subtilis and P. aeruginosa, with MIC values of $112.5 \mu \mathrm{M}$ and $56.25 \mu \mathrm{M}$ respectively, and exerted almost comparable inhibitory activity 
with respect to the standard drug Chloramphenicol against $E$. coli (ATCC25922). Surprisingly, compound $\mathbf{5 b}$ was observed to show potent activity against methicillin-resistant $S$. aureus (N315) with an MIC value of $450 \mu \mathrm{M}$.

Generally, the halobenzyloxy triazole derivatives $\mathbf{3 a}, \mathbf{3 b}, \mathbf{3 c}$ and $\mathbf{4 d}$ along with their hydrochlorides $\mathbf{5 a}, \mathbf{5 b}, \mathbf{5 c}$ and $\mathbf{6 d}$ containing dichlorobenzyloxy, difluorobenzyloxy, 4-fluorobenzyloxy and dodecyloxy moieties respectively, showed more potent antibacterial activity than other new compounds against some tested bacteria species, while the hydrochlorides with better water solubility exhibited enhanced activity in contrast to their corresponding compounds. All the results suggested the significant effect of the water-solubility of the compounds, the substitution of benzyloxy group as well as the length of linear alkyl chain in the 1,2,4-triazole ring on antibacterial activity.

Antifungal activity: The antifungal evaluation revealed that for almost all the synthesized halobenzyloxy and alkoxy 1,2,4triazole derivatives, the activities were relatively weak compared to their antibacterial efficacy. However, it's worth mentioning that the 1,2,4-triazole hydrochlorides $\mathbf{5} \mathbf{a}$ and $\mathbf{5} \mathbf{b}$ displayed higher inhibitory activities against $A$. fumigatus than the reference drug Fluconazole with the low MIC values of $800 \mu \mathrm{M}$ and $450 \mu \mathrm{M}$, respectively. All the newly synthesized compounds almost had no obvious inhibitory activity against $C$. albicans except for compounds 5a with 2,4-difluorobenzyloxy group and 6d consisting of the linear alkyl chain with length in $\mathrm{C} 12$, which showed remarkable antifungal activity toward $C$. albicans with MIC values of $200 \mu \mathrm{M}$ and $390 \mu \mathrm{M}$, respectively. The other compounds exhibited poor or weak antifungal activity against all fungi tested.

\section{Conclusion}

In summary, a new type of halobenzyloxy 1,2,4-triazoles (3a-g) and alkoxy 1,2,4-triazoles (4a-e) as well as their corresponding hydrochlorides (5a-g, 6a-e) were synthesized successfully via cyclization using phenylhydrazine as starting material, and their antimicrobial activities were also evaluated. All these new compounds were confirmed by IR, MS, ${ }^{1} \mathrm{H}$ NMR spectra and elemental analyses. All results obtained from antibacterial and antifungal tests revealed that some of the present series carrying dihalobenzyloxy, octyloxy or dodecyloxy groups exhibited moderate antimicrobial activities in vitro. Noticeably, compound $\mathbf{3 b}$ containing difluorobenzyloxy and its hydrochloride $\mathbf{5} \mathbf{b}$ showed the most potent activity against $P$. aeruginosa and E. coli with the MIC values of $112.5 \mu \mathrm{M}$ and $56.25 \mu \mathrm{M}$ respectively. The study of preliminary structure-activity relationships delineated that the type of substituent and the length of alkyl chain in the new compounds are responsible for the variation of the antimicrobial activities. Moreover, the water-solubility of the tested compounds has important effect on their biological activities. Further investigations are in progress for this class of heterocyclic compounds.

\section{Experimental}

Chemistry. Melting points are uncorrected and were recorded on X-6 melting point apparatus. Thin layer chromatography
(TLC) was performed using pre-coated silica gel plates and visualization was obtained by exposure to iodine vapors and / or under UV light (254 nm). FT-IR spectra were recorded on Bruker RFS100/S spectrophotometer (USA) using KBr pellets in the $400-4000 \mathrm{~cm}^{-1}$ range. ${ }^{1} \mathrm{H}-\mathrm{NMR}$ spectra were determined with a Bruker AV $300 \mathrm{MHz}$ spectrometer and were reported in $\delta$ units (ppm) relative to tetramethylsilane (TMS) as an internal standard. The chemical shifts are expressed in parts per million (d) and following abbreviations were used: $\mathrm{s}=$ singlet; $\mathrm{bs}=$ broad singlet; $\mathrm{d}=$ doublet; $\mathrm{t}=$ triplet; $\mathrm{m}=$ multiplet. The mass spectra were recorded on FINNIGAN TRACE GC-MS 2000 mass spectrometer (Thermo Electron Corporation, Bremen, Germany). Elemental analyses were carried out on a ERBA1106 (Carlo Erba, Milan, Italy). All chemicals and solvents were commercially available, reagent grade, and were used without further purification.

Synthesis of 1-phenyl-1H-1,2,4-triazol-3-ol (2). The mixture of phenylhydrazine (2.8 g, $26 \mathrm{mmol})$ and urea (4.9 g, $82 \mathrm{mmol})$ was dissolved in $6 \mathrm{~mL} \mathrm{H}_{2} \mathrm{O}$ with stirring at $90^{\circ} \mathrm{C}$. Subsequently, concentrated sulfuric acid (4.2 g, $42 \mathrm{mmol})$ was added by a dropping funnel with stirring. After that, the mixture was refluxed for $5-9 \mathrm{~h}$ at $100^{\circ} \mathrm{C}$ until the starting material was almost consumed (monitored by TLC, eluent, chloroform/acetone, 10/1, $\mathrm{v} / \mathrm{v}$ ), and then set down the temperature to $90^{\circ} \mathrm{C}$, added $\mathrm{HCO}$ $\mathrm{OH}(3.7 \mathrm{~g}, 82 \mathrm{mmol})$ to the flask and stirred for $16-20 \mathrm{~h}$ under $125^{\circ} \mathrm{C}$ until the reaction was over (monitored by TLC, eluent, chloroform/acetone, $3 / 1, \mathrm{v} / \mathrm{v}$ ). The reacting mixture was cooled to room temperature, and then the resultant yellow precipitate was filtered and washed with water until $\mathrm{pH}$ 6.5. The crude product was purified by recrystallization from acetic acid to afford white solid in $88 \%$ yield, mp $281-282^{\circ} \mathrm{C}$, which is according with the reference. ${ }^{35}$

Synthesis of halobenzyloxy 1,2,4-triazoles (3a-g). To a flask containing hydroxyltriazole $2(200 \mathrm{mg})$ in $10 \mathrm{~mL} \mathrm{CH}_{3} \mathrm{CN}$ was added $200 \mathrm{mg}$ ( $14.5 \mathrm{mmol})$ of anhydrous potassium carbonate and stirred for $30 \mathrm{~min}$ at $65^{\circ} \mathrm{C}$. Then $5 \mathrm{mg}$ of tetrabutyl ammonium iodide (TBAI) and equimolar halobenzyl bromide or chloride were added and the mixture was stirred at $70-75^{\circ} \mathrm{C}$ for 5 $7 \mathrm{~h}$ (monitored by TLC, eluent, chloroform). After cooling, the reaction mixture was evaporated under reduced pressure, treated with water $(10 \mathrm{~mL})$, and then extracted with chloroform $(3 \times 10$ $\mathrm{mL})$. The organic layers were combined, dried over anhydrous $\mathrm{Na}_{2} \mathrm{SO}_{4}$, and concentrated under reduced pressure. The resulting residue was purified via silica gel column chromatography (eluent, chloroform) and recrystallized from the mixture solvent of chloroform and petroleum ether $\left(30-60{ }^{\circ} \mathrm{C}\right)$ to yield the compounds 3a-g.

3-(2,4-Dichlorobenzyloxy)-1-phenyl-1 $H$-1,2,4-triazole (3a): This compound 3a (342 mg) was obtained as colourless needles in $86 \%$ yield, $\mathrm{mp} 138-139^{\circ} \mathrm{C}$; IR (KBr) v 3122, 3072 (Ar-H), 2921, $2868\left(\mathrm{CH}_{2}\right), 1600,1553,1448,1410,1361$ (aromatic frame), 1250, 1094 (C-O-C), 869, 859, 813, 736, $637 \mathrm{~cm}^{-1}$; ${ }^{1} \mathrm{H}-\mathrm{NMR}\left(300 \mathrm{MHz}, \mathrm{CDCl}_{3}, J\right.$ in Hz) $\delta 8.28(\mathrm{~s}, 1 \mathrm{H}$, triazole $5-\mathrm{H})$, 7.64-7.58 (m, 3H, Ar H), 7.49 (t, 2H, $\left.{ }^{3} J=7.60, \mathrm{Ar} \mathrm{H}\right), 7.43-7.37$ (m, 2H, Ar H), 7.30-7.29 (m, 1H, Ar H), 5.48 (s, 2H, OCH $)$ ppm; MS m/z 320 [M] ; Anal. Calcd. for $\mathrm{C}_{15} \mathrm{H}_{11} \mathrm{Cl}_{2} \mathrm{~N}_{3} \mathrm{O}$ : C, 56.32; H, 3.50; N, 13.16. Found: C, 56.27; H, 3.46; N, 13.12.

3-(2,4-Difluorobenzyloxy)-1-phenyl-1H-1,2,4-triazole 
(3b): This compound $\mathbf{3 b}(316 \mathrm{mg})$ was obtained as white solid in $88 \%$ yield, mp $100-101{ }^{\circ} \mathrm{C}$. IR (KBr) v 3131, 3084 (Ar-H), 2968, $2968\left(\mathrm{CH}_{2}\right), 1622,1546,1473,1445,1333$ (aromatic frame), 1280, 1080 (C-O-C), 853, 830, 787, 739, $672 \mathrm{~cm}^{-1}$; ${ }^{1} \mathrm{H}-$ NMR $\left(300 \mathrm{MHz}, \mathrm{CDCl}_{3}, J\right.$ in $\left.\mathrm{Hz}\right) \delta 8.28(\mathrm{~s}, 1 \mathrm{H}$, triazole $5-\mathrm{H})$, 7.64-7.58 (m, 2H, Ar H), 7.56-7.53 (m, 1H, Ar H), 7.51-7.48 (m, 2H, Ar H), 7.46-7.36 (m, 1H, Ar H), 6.89-6.82 (m, 2H, Ar H), 5.47 (s, 2H, $\left.\mathrm{OCH}_{2}\right)$ ppm; MS m/z $288[\mathrm{M}+\mathrm{H}]^{+}$; Anal. Calcd. for $\mathrm{C}_{15} \mathrm{H}_{11} \mathrm{~F}_{2} \mathrm{~N}_{3} \mathrm{O}$ : C, 62.76; H, 3.90; N, 14.64. Found: C, 62.72; $\mathrm{H}, 3.86$; N, 14.63.

3-(4-Fluorobenzyloxy)-1-phenyl-1H-1,2,4-triazole (3c): This compound 3c (297 mg) was obtained as white solid in $89 \%$ yield, mp 102 - $103{ }^{\circ} \mathrm{C}$; IR (KBr) v 3122, 3065 (Ar-H), 2972, 2853 $\left(\mathrm{CH}_{2}\right), 1599,1555,1480,1452,1332$ (aromatic frame), 1222, 1055 (C-O-C), 859, 823, 805, 757, $680 \mathrm{~cm}^{-1}$; ${ }^{1} \mathrm{H}-\mathrm{NMR}(300$ $\mathrm{MHz}, \mathrm{CDCl}_{3}, J$ in $\left.\mathrm{Hz}\right) \delta 8.26(\mathrm{~s}, 1 \mathrm{H}$, triazole $5-\mathrm{H}), 7.62(\mathrm{~d}, 2 \mathrm{H}$, ${ }^{3} J=7.83, \mathrm{ArH}$ ), 7.51-7.45 (m, 4H, Ar H), 7.38-7.33 (t, $1 \mathrm{H},{ }^{3} J=$ 7.32, $\mathrm{ArH}$ ), 7.10-7.04 (t, 2H, $\left.{ }^{3} J=8.64, \mathrm{ArH}\right), 5.37$ (s, 2H, OCH $)$ ppm; MS m/z $270[\mathrm{M}+\mathrm{H}]^{+}$; Anal. Calcd. for $\mathrm{C}_{15} \mathrm{H}_{12} \mathrm{FN}_{3} \mathrm{O}: \mathrm{C}$, 66.94; H, 4.53; N, 15.64. Found: C, 66.91; H, 4.49; N, 15.60.

3-(3,4-Dichlorobenzyloxy)-1-phenyl-1H-1,2,4-triazole (3d): This compound $\mathbf{3 d}$ (337 mg) was obtained as white solid in $85 \%$ yield, mp $98-100{ }^{\circ} \mathrm{C}$; IR (KBr) v 3122, $3089(\mathrm{Ar}-\mathrm{H})$, 2973, $2915\left(\mathrm{CH}_{2}\right), 1597,1568,1479,1448,1329$ (aromatic frame), 1234, 1056 (C-O-C), 860, 824, 799, 758, $689 \mathrm{~cm}^{-1} ;{ }^{1} \mathrm{H}-$ NMR (300 MHz, $\mathrm{CDCl}_{3}, J$ in $\left.\mathrm{Hz}\right) \delta 8.27(\mathrm{~s}, 1 \mathrm{H}$, triazole 5-H), 7.62 (d, 3H, ${ }^{3} J=8.22$, Ar H), 7.51-7.44 (m, 3H, Ar H), 7.39-7.32 (m, 2H, Ar H), 5.36 (s, 2H, OCH $H_{2}$ ppm; MS m/z $320[\mathrm{M}]^{+}$; Anal. Calcd. for Anal. Calcd. for $\mathrm{C}_{15} \mathrm{H}_{11} \mathrm{Cl}_{2} \mathrm{~N}_{3} \mathrm{O}$ : C, 56.30; $\mathrm{H}$, 3.50; N, 13.17. Found: C, 56.27; H, 3.46; N, 13.12 .

3-(2-Chlorobenzyloxy)-1-phenyl-1H-1,2,4-triazole (3e): This compound 3e (315 mg) was obtained as white solid in $89 \%$ yield, mp 123 - $125^{\circ} \mathrm{C}$; IR (KBr) v 3121, 3092 (Ar-H), 2973, 2869 $\left(\mathrm{CH}_{2}\right), 1599,1565,1458,1435,1332$ (aromatic frame), 1234, 1047 (C-O-C), 870, 846, 774, 746, $678 \mathrm{~cm}^{-1}$; ${ }^{1} \mathrm{H}-\mathrm{NMR}(300$ $\mathrm{MHz}, \mathrm{CDCl}_{3}, J$ in $\left.\mathrm{Hz}\right) \delta 7.84(\mathrm{~s}, 1 \mathrm{H}$, triazole 5-H), 7.49-7.45 (m,

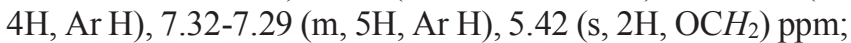
MS m/z 285 [M] ; Anal. Calcd. for $\mathrm{C}_{15} \mathrm{H}_{12} \mathrm{ClN}_{3} \mathrm{O}: \mathrm{C}, 63.09 ; \mathrm{H}$, 4.29; N, 14.75. Found: C, 63.05; H, 4.23; N, 14.71.

3-(4-Chlorobenzyloxy)-1-phenyl-1H-1,2,4-triazole (3f): This compound $\mathbf{3 f}$ (304 $\mathrm{mg}$ ) was obtained as white solid in $86 \%$ yield, mp $130-131{ }^{\circ} \mathrm{C}$; IR (KBr) v 3120, 3056 (Ar-H), 2970, $2852\left(\mathrm{CH}_{2}\right), 1597,1568,1479,1448,1334$ (aromatic frame), 1234, 1056 (C-O-C), 863, 846, 811, 758, $688 \mathrm{~cm}^{-1}$; ${ }^{1} \mathrm{H}-\mathrm{NMR}$ $\left(300 \mathrm{MHz} \mathrm{CDCl}_{3}, J\right.$ in $\left.\mathrm{Hz}\right) \delta 8.27(\mathrm{~s}, 1 \mathrm{H}$, triazole 5-H), $7.62(\mathrm{~d}$, $\left.3 \mathrm{H},{ }^{3} J=7.83, \mathrm{Ar} \mathrm{H}\right), 7.51-7.44$ (m, 4H, Ar H), 7.38-7.34 (m, 2H, $\mathrm{ArH}$ ), 5.38 (s, 2H, OCH ) ppm; MS m/z 285 [M] ; Anal. Calcd. for $\mathrm{C}_{15} \mathrm{H}_{12} \mathrm{ClN}_{3} \mathrm{O}$ : C, 63.07; H, 4.25; N, 14.75. Found: C, 63.05; $\mathrm{H}, 4.23 ; \mathrm{N}, 14.71$.

3-(3-Chlorobenzyloxy)-1-phenyl-1 H-1,2,4-triazole (3g): This compound $\mathbf{3 g}$ (308 $\mathrm{mg}$ ) was obtained as white solid in $87 \%$ yield, mp $104-106^{\circ} \mathrm{C}$; IR (KBr) v 3121, 3070 (Ar-H), 2973, $2852\left(\mathrm{CH}_{2}\right), 1598,1551,1478,1448,1337$ (aromatic frame), 1235, 1054 (C-O-C), 860, 836, 784, 756, $688 \mathrm{~cm}^{-1}$; ${ }^{1} \mathrm{H}-\mathrm{NMR}$ $\left(300 \mathrm{MHz} \mathrm{CDCl}_{3}, J\right.$ in $\left.\mathrm{Hz}\right) \delta 8.27(\mathrm{~s}, 1 \mathrm{H}$, triazole 5-H), $7.62(\mathrm{~d}$, $\left.2 \mathrm{H},{ }^{3} \mathrm{~J}=7.86, \mathrm{Ar} \mathrm{H}\right), 7.52-7.45$ (m, 3H, Ar H), 7.38-7.36 (m, 2H,

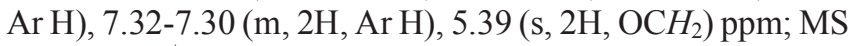
m/z $285[\mathrm{M}]^{+}$; Anal. Calcd. for $\mathrm{C}_{15} \mathrm{H}_{12} \mathrm{ClN}_{3} \mathrm{O}: \mathrm{C}, 63.06 ; \mathrm{H}, 4.30$;
N, 14.75. Found: C, 63.05; H, 4.28; N, 14.71.

Synthesis of alkoxy 1,2,4-triazoles (4a-e). A suspension of hydroxytriazole $2(200 \mathrm{mg})$ and anhydrous potassium carbonate (200 mg, $14.5 \mathrm{mmol}, 1.2$ equiv) in $\mathrm{CH}_{3} \mathrm{CN}(10 \mathrm{~mL})$ was stirred for $30 \mathrm{~min}$ at $65^{\circ} \mathrm{C}$. Then tetrabutyl ammonium iodide (TBAI, 5 $\mathrm{mg}$ ) and equimolar alkyl bromide were added to the suspension and the mixture was stirred at $70-75^{\circ} \mathrm{C}$ for $5-7 \mathrm{~h}$ (monitored by TLC, eluent, chloroform). After cooling, the solvent was evaporated under reduced pressure. Then, the residue was poured into water $(10 \mathrm{~mL})$ and extracted with chloroform $(3 \times 10 \mathrm{~mL})$. The organic layer was separated, dried over anhydrous $\mathrm{Na}_{2} \mathrm{SO}_{4}$ and evaporated under reduced pressure to give the crude product, which was purified by silica gel column chromatography (eluent, chloroform) to give the desired compounds $4 \mathbf{a}-\mathbf{e}$.

2-(1-Phenyl-1H-1,2,4-triazol-3-yloxy)ethanol (4a): This compound $4 \mathbf{a}(143 \mathrm{mg})$ was obtained as white solid in $56 \%$ yield, mp $132-133{ }^{\circ} \mathrm{C}$; IR (KBr) v 3512 (O-H), 3153, 3099 (Ar$\mathrm{H}), 2973,2894\left(\mathrm{CH}_{2}\right), 1607,1596,1498,1464,1321$ (aromatic frame), 1241, 1092 (C-O-C), 1015 (C-O), 894, 841, 752, 664 $\mathrm{cm}^{-1}$; ${ }^{\mathrm{H}}-\mathrm{NMR}\left(300 \mathrm{MHz}, \mathrm{CDCl}_{3}, J\right.$ in $\left.\mathrm{Hz}\right) \delta 8.28(\mathrm{~s}, 1 \mathrm{H}$, triazole $5-\mathrm{H}), 7.62\left(\mathrm{~d}, 2 \mathrm{H},{ }^{3} J=7.86, \mathrm{Ph} 2,6-\mathrm{H}\right), 7.50$ (t, $2 \mathrm{H},{ }^{3} J=7.41, \mathrm{Ph}$ 3,5-H), 7.37 (t, $\left.1 \mathrm{H},{ }^{3} \mathrm{~J}=7.26, \mathrm{Ph} 4-\mathrm{H}\right), 4.51\left(\mathrm{t}, 2 \mathrm{H},{ }^{3} \mathrm{~J}=3.81\right.$, $\mathrm{OCH}_{2} \mathrm{CH}_{2} \mathrm{OH}$ ), 4.00 (t, $2 \mathrm{H},{ }^{3} \mathrm{~J}=4.02, \mathrm{OCH}_{2} \mathrm{CH}_{2} \mathrm{OH}$ ) ppm; MS $m / z 206[\mathrm{M}]^{+}$; Anal. Calcd. for $\mathrm{C}_{10} \mathrm{H}_{11} \mathrm{~N}_{3} \mathrm{O}_{2}$ : C, 58.56; H, 5.43; N, 20.51. Found: C, 58.53; H, 5.40; N, 20.48.

3-Butoxy-1-phenyl-1H-1,2,4-triazole (4b): This compound 4b (135 mg) was obtained as colorless liquid in 50\% yield; ${ }^{1} \mathrm{H}-\mathrm{NMR}\left(300 \mathrm{MHz}, \mathrm{CDCl}_{3}, J\right.$ in $\left.\mathrm{Hz}\right) \delta 8.28(\mathrm{~s}, 1 \mathrm{H}$, triazole $5-\mathrm{H})$, $7.62\left(\mathrm{~d}, 2 \mathrm{H},{ }^{3} \mathrm{~J}=7.55, \mathrm{Ph} 2,6-\mathrm{H}\right), 7.37$ (t, $2 \mathrm{H},{ }^{3} J=7.42$, Ph 3,5H), $7.36\left(\mathrm{t}, 1 \mathrm{H},{ }^{3} J=7.08\right.$, Ph 4-H), $4.34\left(\mathrm{t}, 2 \mathrm{H},{ }^{3} J=6.45, \mathrm{OCH}_{2}\right)$, 1.64-1.61 (m, 2H, OCH $\left.\mathrm{CH}_{2}\right), 1.43-1.40\left(\mathrm{~m}, 2 \mathrm{H}, \mathrm{CH}_{2} \mathrm{CH}_{3}\right), 0.96$ (t, 3H, $\mathrm{CH}_{3}$ ) ppm; MS m/z 217 [M] ${ }^{+}$; Anal. Calcd. for $\mathrm{C}_{12} \mathrm{H}_{15^{-}}$ $\mathrm{N}_{3} \mathrm{O}$ : C, 66.37; H, 7.01; N, 19.38. Found: C, 66.34; H, 6.96; N, 19.34 .

3-(Octyloxy)-1-phenyl-1H-1,2,4-triazole (4c): This compound $4 \mathrm{c}(221 \mathrm{mg})$ was obtained as white solid in $66 \%$ yield, mp 57 - $58^{\circ} \mathrm{C}$; IR (KBr) v 3126, $3088(\mathrm{Ar}-\mathrm{H}), 2983,2896\left(\mathrm{CH}_{2}\right)$, $1607,1597,1478,1437,1337$ (aromatic frame), 1237, 1033 (C$\mathrm{O}-\mathrm{C}), 883,842,785,756,681 \mathrm{~cm}^{-1}$; ${ }^{1} \mathrm{H}-\mathrm{NMR}\left(300 \mathrm{MHz}, \mathrm{CDCl}_{3}\right.$, $J$ in $\mathrm{Hz}) \delta 8.25(\mathrm{~s}, 1 \mathrm{H}$, triazole $5-\mathrm{H}), 7.89\left(\mathrm{~d}, 2 \mathrm{H},{ }^{3} J=6.75, \mathrm{Ph}\right.$ 2,6-H), 7.47 (t, 2H, $\left.{ }^{3} J=7.50, \mathrm{Ph} 3,5-\mathrm{H}\right), 7.34$ (t, $1 \mathrm{H},{ }^{3} J=7.18, \mathrm{Ph}$ $4-\mathrm{H}), 4.35\left(\mathrm{t}, 2 \mathrm{H},{ }^{3} \mathrm{~J}=6.54, \mathrm{OCH}_{2}\right), 1.75-1.69\left(\mathrm{~m}, 2 \mathrm{H}, \mathrm{OCH}_{2-}\right.$ $\left.\mathrm{CH}_{2}\right), 1.46-1.43\left(\mathrm{~m}, 10 \mathrm{H},\left(\mathrm{CH}_{2}\right)_{5} \mathrm{CH}_{3}\right), 0.87$ (t, $\left.3 \mathrm{H}, \mathrm{CH}_{2} \mathrm{CH}_{3}\right)$ ppm; MS m/z $270[\mathrm{M}]^{+}$; Anal. Calcd. for $\mathrm{C}_{16} \mathrm{H}_{23} \mathrm{~N}_{3} \mathrm{O}$ : C, 70.34; H, 8.51; N, 15.40. Found: C, 70.30; H, 8.48; N, 15.37.

3-(Dodecyloxy)-1-phenyl-1H-1,2,4-triazole (4d): This compound $4 \mathbf{d}(221 \mathrm{mg})$ was obtained as white solid in 54\% yield, mp $81-82^{\circ} \mathrm{C}$; IR (KBr) v 3127, $3062(\mathrm{Ar}-\mathrm{H}), 2977,2889\left(\mathrm{CH}_{2}\right)$, $1611,1596,1464,1435,1331$ (aromatic frame), 1235, 1026 (CO-C), 887, 846, 784, 757, $669 \mathrm{~cm}^{-1}$; ${ }^{1} \mathrm{H}-\mathrm{NMR}\left(300 \mathrm{MHz}, \mathrm{CDCl}_{3}\right.$, $J$ in $\mathrm{Hz}) \delta 8.25(\mathrm{~s}, 1 \mathrm{H}$, triazole $5-\mathrm{H}), 7.62\left(\mathrm{~d}, 2 \mathrm{H},{ }^{3} J=7.86, \mathrm{Ph}\right.$ 2,6-H), 7.47 (t, 2H, $\left.{ }^{3} J=7.70, \mathrm{Ph} 3,5-\mathrm{H}\right), 7.35$ (t, $1 \mathrm{H},{ }^{3} J=7.35, \mathrm{Ph}$ $4-\mathrm{H}), 4.35\left(\mathrm{t}, 2 \mathrm{H},{ }^{3} \mathrm{~J}=6.57, \mathrm{OCH}_{2}\right), 1.81-1.78\left(\mathrm{~m}, 2 \mathrm{H}, \mathrm{OCH}_{2}-\right.$ $\left.\mathrm{CH}_{2}\right), 1.49-1.43\left(\mathrm{~m}, 2 \mathrm{H}, \mathrm{OCH}_{2} \mathrm{CH}_{2} \mathrm{CH}_{2}\right), 1.28-1.25$ (m, $16 \mathrm{H}$, $\left.\left(\mathrm{CH}_{2}\right)_{8} \mathrm{CH}_{3}\right), 0.87$ (t, 3H, $\left.\mathrm{CH}_{2} \mathrm{CH}_{3}\right)$ ppm; $\mathrm{MS} \mathrm{m} / \mathrm{z} 330[\mathrm{M}]^{+}$; Anal. Calcd. for $\mathrm{C}_{20} \mathrm{H}_{31} \mathrm{~N}_{3} \mathrm{O}: \mathrm{C}, 73.96 ; \mathrm{H}, 9.52 ; \mathrm{N}, 12.79$. Found: C, 72.91; H, 9.48; N, 12.75 .

3-(Hexadecyloxy)-1-phenyl-1H-1,2,4-triazole (4e): This 
compound 4e (320 mg) was obtained as white solid in $67 \%$ yield, mp $111-112^{\circ} \mathrm{C}$; IR (KBr) v 3132, 3089 (Ar-H), 2973, $2882\left(\mathrm{CH}_{2}\right), 1602,1596,1478,1448,1321$ (aromatic frame), 1243, 1044 (C-O-C), 895, 838, 795, 766, $677 \mathrm{~cm}^{-1}$; ${ }^{1} \mathrm{H}-\mathrm{NMR}$ $\left(400 \mathrm{MHz}, \mathrm{CDCl}_{3}, J\right.$ in $\left.\mathrm{Hz}\right) \delta 8.24(\mathrm{~s}, 1 \mathrm{H}$, triazole $5-\mathrm{H}), 7.62$ (d, $\left.2 \mathrm{H},{ }^{3} J=8.0, \mathrm{Ph} 2,6-\mathrm{H}\right), 7.47$ (t, $\left.2 \mathrm{H},{ }^{3} J=7.85, \mathrm{Ph} 3,5-\mathrm{H}\right)$, $7.34\left(\mathrm{t}, 1 \mathrm{H},{ }^{3} \mathrm{~J}=7.5, \mathrm{Ph} 4-\mathrm{H}\right), 4.34\left(\mathrm{t}, 2 \mathrm{H},{ }^{3} \mathrm{~J}=6.60, \mathrm{OCH}_{2}\right), 1.86-$ $1.78\left(\mathrm{~m}, 2 \mathrm{H}, \mathrm{OCH}_{2} \mathrm{CH}_{2}\right), 1.48-1.43\left(\mathrm{~m}, 2 \mathrm{H}, \mathrm{OCH}_{2} \mathrm{CH}_{2} \mathrm{CH}_{2}\right)$, $1.25\left(\mathrm{~m}, 24 \mathrm{H},\left(\mathrm{CH}_{2}\right)_{12} \mathrm{CH}_{3}\right), 0.87$ (t, 3H, $\left.\mathrm{CH}_{2} \mathrm{CH}_{3}\right) \mathrm{ppm} ; \mathrm{MS} \mathrm{m} / z$ $385[\mathrm{M}]^{+}$; Anal. Calcd. for $\mathrm{C}_{24} \mathrm{H}_{39} \mathrm{~N}_{3} \mathrm{O}: \mathrm{C}, 74.78 ; \mathrm{H}, 10.20 ; \mathrm{N}$, 10.94. Found: C, 74.76; H, 10.19; N, 10.90.

Synthesis of halobenzyloxy 1,2,4-triazole hydrochlorides (5a-g). To a solution of halobenzyloxy 1,2,4-triazoles 3a-g (100 $\mathrm{mg})$ in ethyl ether $(10 \mathrm{~mL})$ was added hydrochloride acid (10 $\mathrm{mL}, 4 \mathrm{~mol} / \mathrm{L})$. The mixture was stirred at room temperature for $5-6 \mathrm{~h}$ and the solvent was evaporated to afford the corresponding hydrochlorides 5a-g. Some salts were highly hydroscopic and no sharp melting points could be observed.

3-(2,4-Dichlorobenzyloxy)-1-phenyl-1 H-1,2,4-triazole hydrochloride (5a): This hydrochloride $\mathbf{5 a}(98 \mathrm{mg}$ ) was obtained as white solid in $88 \%$ yield, mp $238-239^{\circ} \mathrm{C}$; IR (KBr) $\vee 3132$, 3085 (Ar- H), 2945, $2874\left(\mathrm{CH}_{2}\right), 1635,1573,1469,1446,1341$ (aromatic frame), 1265, 1079 (C-O-C), 887, 863, 825, 748, $645 \mathrm{~cm}^{-1} ;{ }^{1} \mathrm{H}-\mathrm{NMR}\left(300 \mathrm{MHz}, \mathrm{DMSO}-d_{6}\right) \delta 8.77(\mathrm{~s}, 1 \mathrm{H}$, triazole 5-H), 7.85- 7.80 (m, 3H, Ar H), 7.59-7.54 (m, 2H, Ar $\mathrm{H}), 7.41-7.37$ (m, 2H, Ar H), 7.36-7.30 (m, 1H, Ar H), 5.57 (s, $\left.2 \mathrm{H}, \mathrm{OCH}_{2}\right) \mathrm{ppm} ; \mathrm{MS} \mathrm{m} / z 320$ [M-HCl] .

3-(2,4-Difluorobenzyloxy)-1-phenyl-1H-1,2,4-triazole hydrochloride (5b): This hydrochloride $\mathbf{5 b}$ (96 mg) was obtained as white solid in $88 \%$ yield; No sharp melting points; IR ( $\mathrm{KBr}$ ) v 3143, 3092 (Ar-H), 2974, $2970\left(\mathrm{CH}_{2}\right), 1641,1562,1494,1467$, 1369 (aromatic frame), 1295, 1107 (C-O-C), 874, 842, 790, 742, $673 \mathrm{~cm}^{-1}$; ${ }^{1} \mathrm{H}-\mathrm{NMR}\left(300 \mathrm{MHz}, \mathrm{DMSO}-d_{6}\right) \delta 8.68(\mathrm{~s}, 1 \mathrm{H}$, triazole 5-H), 7.84-7.80 (m, 2H, Ar H), 7.63-7.60 (m, 1H, Ar H), 7.577.53 (m, 2H, Ar H), 7.41-7.38 (m, 1H, Ar H), 7.04-7.01 (m, 2H, Ar H), 5.51 (s, 2H, OCH $H_{2}$ ppm; MS m/z $288[\mathrm{M}-\mathrm{Cl}]^{+}$.

3-(4-Fluorobenzyloxy)-1-phenyl-1H-1,2,4-triazole hydrochloride (5c): This hydrochloride $\mathbf{5 c}(98 \mathrm{mg})$ was obtained as white solid in $86 \%$ yield; $215-217^{\circ} \mathrm{C}$; IR (KBr) v 3140,3076 (Ar-H), 2981, $2869\left(\mathrm{CH}_{2}\right), 1613,1563,1485,1459,1342$ (aromatic frame), 1254, 1095 (C-O-C), 863, 829, 805, 764, $686 \mathrm{~cm}^{-1}$; ${ }^{1} \mathrm{H}-\mathrm{NMR}\left(300 \mathrm{MHz}, \mathrm{DMSO}-d_{6}\right) \delta 8.61(\mathrm{~s}, 1 \mathrm{H}$, triazole $5-\mathrm{H})$, 7.88-7.84 (m, 4H, Ar H), 7.70-7.67 (m, 2H, Ar H), 7.49-7.46 (m,

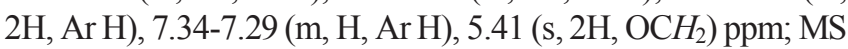
$\mathrm{m} / \mathrm{z} 270[\mathrm{M}-\mathrm{Cl}]^{+}$.

3-(3,4-Dichlorobenzyloxy)-1-phenyl-1H-1,2,4-triazole hydrochloride (5d): This hydrochloride $\mathbf{5 d}$ (96 mg) was obtained as white solid in $86 \%$ yield, mp $176-178^{\circ} \mathrm{C}$; IR (KBr) $\vee 3135$, 3076 (Ar-H), 2985, $2937\left(\mathrm{CH}_{2}\right), 1623,1575,1487,1450,1339$ (aromatic frame), 1254, 1091 (C-O-C), 867, 834, 782, 755, 689 $\mathrm{cm}^{-1} ;{ }^{1} \mathrm{H}-\mathrm{NMR}\left(300 \mathrm{MHz}, \mathrm{DMSO}-d_{6}\right) \delta 8.84(\mathrm{~s}, 1 \mathrm{H}$, triazole 5H), 7.85-7.87 (m, 3H, Ar H), 7.69-7.64 (m, 3H, Ar H), 7.45-7.40 (m, 2H, Ar H), 5.43 (s, 2H, OCH $)$ ppm; MS m/z $320[\mathrm{M}-\mathrm{HCl}]^{+}$.

3-(2-Chlorobenzyloxy)-1-phenyl-1H-1,2,4-triazole hydrochloride (5e): This hydrochloride $\mathbf{5 e}(91 \mathrm{mg})$ was obtained as white solid in $81 \%$ yield, mp $191-193{ }^{\circ} \mathrm{C}$; IR (KBr) v 3137 , 3090 (Ar-H), 2981, $2884\left(\mathrm{CH}_{2}\right), 1619,1570,1454,1432,1339$ (aromatic frame), 1260, 1084 (C-O-C), 879, 849, 784, 745, 678 $\mathrm{cm}^{-1} ;{ }^{1} \mathrm{H}-\mathrm{NMR}\left(300 \mathrm{MHz}, \mathrm{DMSO}-d_{6}\right) \delta 8.64(\mathrm{~s}, 1 \mathrm{H}$, triazole 5$\mathrm{H}), 7.79-7.72$ (m, 4H, Ar H), 7.47-7.42 (m, 5H, Ar H), 5.49 (s, $\left.2 \mathrm{H}, \mathrm{OCH}_{2}\right) \mathrm{ppm} ; \mathrm{MS} m / z 285[\mathrm{M}-\mathrm{HCl}]^{+}$.

3-(4-Chlorobenzyloxy)-1-phenyl-1H-1,2,4-triazole hydrochloride (5f): This hydrochloride $\mathbf{5 f}$ (94 $\mathrm{mg}$ ) was obtained as white solid in $83 \%$ yield, mp $209-211^{\circ} \mathrm{C}$; IR (KBr) v 3143 , 3079 (Ar-H), 2991, $2847\left(\mathrm{CH}_{2}\right), 1623,1575,1477,1454,1341$ (aromatic frame), 1254, 1091 (C-O-C), 876, 854, 819, 760, 688 $\mathrm{cm}^{-1}$; ${ }^{1} \mathrm{H}-\mathrm{NMR}\left(300 \mathrm{MHz}, \mathrm{DMSO}-d_{6}\right) \delta 8.81(\mathrm{~s}, 1 \mathrm{H}$, triazole 5H), 7.78-7.72 (m, 3H, Ar H), 7.62-7.58 (m, 4H, Ar H), 7.47-7.42

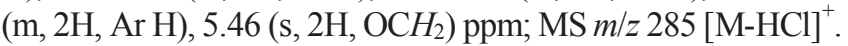

3-(3-Chlorobenzyloxy)-1-phenyl-1H-1,2,4-triazole hydrochloride (5g): This hydrochloride $\mathbf{5 g}(98 \mathrm{mg})$ was obtained as white solid in $87 \%$ yield, mp $172-175^{\circ} \mathrm{C}$; IR (KBr) v 3136 , 3067 (Ar-H), 2982, $2846\left(\mathrm{CH}_{2}\right), 1620,1564,1482,1451,1342$ (aromatic frame), 1248, 1094 (C-O-C), 869, 841, 782, 758, 695 $\mathrm{cm}^{-1}$; ${ }^{1} \mathrm{H}-\mathrm{NMR}\left(300 \mathrm{MHz}, \mathrm{DMSO}-d_{6}\right) \delta 8.79(\mathrm{~s}, 1 \mathrm{H}$, triazole 5H), 7.78-7.74 (m, 2H, Ar H), 7.64-7.60 (m, 3H, Ar H), 7.49-7.45

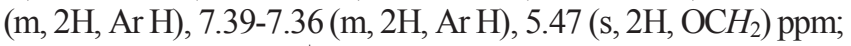
$\mathrm{MS} m / z 285[\mathrm{M}-\mathrm{HCl}]^{+}$.

Synthesis of alkoxy 1,2,4-triazole hydrochlorides (6a-e). To a well-stirred suspension of alkoxy 1,2,4-triazoles 4a-e (100 mg) in ethyl ether $(10 \mathrm{~mL})$ was added hydrochloride acid $(10 \mathrm{~mL}$, $4 \mathrm{~mol} / \mathrm{L}$ ). After the addition, the resulting mixture was stirred at room temperature for $5-6 \mathrm{~h}$, and then the solvent was removed to afford the hydrochlorides $\mathbf{6 a - e}$.

2-(1-Phenyl-1H-1,2,4-triazol-3-yloxy)ethanol hydrochloride (6a): This hydrochloride $\mathbf{6 a}(96 \mathrm{mg})$ was obtained as white solid in $81 \%$ yield, mp $198-201{ }^{\circ} \mathrm{C}$; IR $(\mathrm{KBr}) \vee 3542(\mathrm{O}-\mathrm{H}), 3169$, 3098 (Ar-H), 2984, 2897 ( $\left.\mathrm{CH}_{2}\right), 1626,1604,1512,1479,1346$ (aromatic frame), 1274, 1108 (C-O-C), 1045 (C-O), 899, 854, $752,671 \mathrm{~cm}^{-1}$; ${ }^{1} \mathrm{H}-\mathrm{NMR}\left(300 \mathrm{MHz}, \mathrm{CDCl}_{3}\right) \delta 8.97(\mathrm{~s}, 1 \mathrm{H}$, triazole 5-H), 7.74-7.70 (m, 2H, Ph H), 7.59-7.55 (m, 2H, Ph H), 7.41-7.38 (m, 1H, Ph H), 4.63-4.60 (m, 2H, OCH $\left.\mathrm{CH}_{2} \mathrm{OH}\right)$, 4.13-4.09 (m, 2H, $\left.\mathrm{OCH}_{2} \mathrm{CH}_{2} \mathrm{OH}\right) \mathrm{ppm}$; $\mathrm{MS} \mathrm{m} / z 206[\mathrm{M}-\mathrm{HCl}]^{+}$.

3-Butoxy-1-phenyl-1H-1,2,4-triazole hydrochloride (6b): This hydrochloride $\mathbf{6 b}(97 \mathrm{mg})$ was obtained as colorless liquid in $83 \%$ yield; ${ }^{1} \mathrm{H}-\mathrm{NMR}\left(300 \mathrm{MHz}, \mathrm{CDCl}_{3}\right) \delta 8.94(\mathrm{~s}, 1 \mathrm{H}$, triazole 5-H), 7.73 (m, 2H, Ph-H), 7.49-7.45 (m, 2H, Ph H), 7.40-7.36 $(\mathrm{m}, 1 \mathrm{H}, \mathrm{Ph} \mathrm{H}), 4.45-4.42$ (m, 2H, OCH $), 1.64-1.61$ (m, 2H, $\left.\mathrm{OCH}_{2} \mathrm{CH}_{2}\right), 1.47-1.45\left(\mathrm{~m}, 2 \mathrm{H}, \mathrm{CH}_{2} \mathrm{CH}_{3}\right), 1.01$ (t, $\left.3 \mathrm{H}, \mathrm{CH}_{3}\right) \mathrm{ppm}$; $\mathrm{MS} m / z 217[\mathrm{M}-\mathrm{HCl}]^{+}$.

3-(Octyloxy)-1-phenyl-1H-1,2,4-triazole hydrochloride (6c): This hydrochloride $\mathbf{6 c}(97 \mathrm{mg})$ was obtained as white solid in $85 \%$ yield; mp $101-103{ }^{\circ} \mathrm{C}$; IR (KBr) v 3137, 3089 (Ar-H), 2991, $2895\left(\mathrm{CH}_{2}\right), 1623,1594,1484,1436,1346$ (aromatic frame), 1250, 1047 (C-O-C), 889, 842, 784, 751, $682 \mathrm{~cm}^{-1}$; ${ }^{1} \mathrm{H}-$ NMR (300 MHz, $\left.\mathrm{CDCl}_{3}\right) \delta 8.91(\mathrm{~s}, 1 \mathrm{H}$, triazole 5-H), 7.92-7.88 (m, 2H, Ph H), 7.54-7.50 (m, 2H, Ph H), 7.42-7.39 (m, 1H, Ph $\mathrm{H})$, 4.43-4.40 (m, 2H, OCH $\mathrm{O}_{2}, 1.82-1.79\left(\mathrm{~m}, 2 \mathrm{H}, \mathrm{OCH}_{2} \mathrm{CH}_{2}\right)$, 1.48-1.45 (m, 10H, $\left.\left(\mathrm{CH}_{2}\right)_{5} \mathrm{CH}_{3}\right), 0.86\left(\mathrm{t}, 3 \mathrm{H}, \mathrm{CH}_{3}\right) \mathrm{ppm}$; MS m/z $270[\mathrm{M}-\mathrm{HCl}]^{+}$.

3-(Dodecyloxy)-1-phenyl-1H-1,2,4-triazole hydrochloride (6d): This hydrochloride $\mathbf{6 d}(97 \mathrm{mg})$ was obtained as white solid in $87 \%$ yield; $m p 135-137^{\circ} \mathrm{C}$; IR (KBr) v 3135, $3071(\mathrm{Ar}-\mathrm{H})$, 2984, $2895\left(\mathrm{CH}_{2}\right), 1625,1598,1476,1449,1346$ (aromatic frame), 1251, 1085 (C-O-C), 893, 849, 782, 757, $671 \mathrm{~cm}^{-1}$; ${ }^{1} \mathrm{H}-$ $\operatorname{NMR}\left(300 \mathrm{MHz}, \mathrm{CDCl}_{3}\right) \delta 8.95(\mathrm{~s}, 1 \mathrm{H}$, triazole $5-\mathrm{H}), 7.71-7.68$ 
(m, 2H, Ph H), 7.51-7.48 (m, 2H, Ph H), 7.42-7.39 (m, 1H, Ph $\mathrm{H}), 4.41-4.38\left(\mathrm{~m}, 2 \mathrm{H}, \mathrm{OCH}_{2}\right), 1.85-1.81\left(\mathrm{~m}, 2 \mathrm{H}, \mathrm{OCH}_{2} \mathrm{CH}_{2}\right)$, $1.46-1.42\left(\mathrm{~m}, 2 \mathrm{H}, \mathrm{OCH}_{2} \mathrm{CH}_{2} \mathrm{CH}_{2}\right), 1.26-1.23\left(\mathrm{~m}, 16 \mathrm{H},\left(\mathrm{CH}_{2}\right)_{8}-\right.$ $\left.\mathrm{CH}_{3}\right), 0.88\left(\mathrm{t}, 3 \mathrm{H}, \mathrm{CH}_{3}\right) \mathrm{ppm}$; MS m/z $330[\mathrm{M}-\mathrm{HCl}]^{+}$.

3-(Hexadecyloxy)-1-phenyl-1 H-1,2,4-triazole hydrochloride (6e): This hydrochloride $6 \mathrm{e}(95 \mathrm{mg})$ was obtained as white solid in $87 \%$ yield, mp $181-183{ }^{\circ} \mathrm{C}$; IR (KBr) v 3142, $3095(\mathrm{Ar}-\mathrm{H})$, 2979, $2887\left(\mathrm{CH}_{2}\right), 1632,1611,1495,1451,1336$ (aromatic frame), 1248, 1078 (C-O-C), 897, 845, 799, 771, $686 \mathrm{~cm}^{-1}$; ${ }^{1} \mathrm{H}-$ NMR $\left(300 \mathrm{MHz}, \mathrm{CDCl}_{3}\right) \delta 8.89(\mathrm{~s}, 1 \mathrm{H}$, triazole 5-H), 7.73-7.69 (m, 2H, Ph H), 7.52-7.49 (m, 2H, Ph H), 7.40-7.37 (m, 1H, Ph $\mathrm{H}), 4.42-4.45\left(\mathrm{~m}, 2 \mathrm{H}, \mathrm{OCH}_{2}\right), 1.87-1.85\left(\mathrm{~m}, 2 \mathrm{H}, \mathrm{OCH}_{2} \mathrm{CH}_{2}\right)$, 1.47-1.42 (m, $\left.2 \mathrm{H}, \mathrm{OCH}_{2} \mathrm{CH}_{2} \mathrm{CH}_{2}\right), 1.27-1.23\left(\mathrm{~m}, 24 \mathrm{H},\left(\mathrm{CH}_{2}\right)_{12}\right.$ $\left.\mathrm{CH}_{3}\right), 0.87$ (t, 3H, $\left.\mathrm{CH}_{3}\right) \mathrm{ppm}$; MS m/z $385[\mathrm{M}-\mathrm{HCl}]^{+}$.

Antibacterial and antifungal assays. The in vitro minimal inhibitory concentrations (MICs) of the target compounds were determined by broth microdilution assay method in 96-well microtest plates. ${ }^{36}$ The tested microorganism strains were provided by the School of Pharmaceutical Sciences, Southwest University and the College of Pharmacy, Third Military Medical University. Fluconazole and Chloramphenicol obtained from their respective manufacturers served as controls.

All compounds were evaluated for their antibacterial activities against $S$. aureus (ATCC29213) and B. subtilis as Gram-positive, E. coli (ATCC25922), P. aeruginosa, S. dysenteriae and $E$. typhosa as Gram-negative bacteria, as well as their antifungal activity against $C$. albicans (ATCC76615) and $A$. fumigatus, at the concentrations of the antimicrobial agents ranging from $0.5 \mu \mathrm{g} / \mathrm{mL}$ to $512 \mu \mathrm{g} / \mathrm{mL}$ and scored for $\mathrm{MIC}_{50}$ as the level of growth inhibition of the tested microorganisms. The minimum inhibitory concentration (MIC) values (in $\mu \mathrm{M}$ ) were summarized in Table 1.

Acknowledgments. This work was partially supported by Natural Science Foundation of Chongqing (CSCT: 2007BB5369, 2009BB5296) and Southwest University (SWUB2006018, XSGX0602).

\section{References}

1. (a) Dismukes, W. E. Clin. Infect. Dis. 2006, 42, 1289. (b) DeMarco, C. E.; Cushing, L. A.; Frempont-Manso, E. Antimicrob. Agents Chemother. 2007, 51, 3235. (c) Lorand, T.; Kocsis, B. Mini. Rev. Med. Chem. 2007, 7, 900.

2. Yu, G.-P.; Xu, L.-Z.; Yi, X.; Bi, W.-Z.; Zhu, Q.; Zhai, Z.-W. J. Agric. Food Chem. 2009, 57, 4854.

3. Ming, Z.-H.; Xu, S.-Z.; Zhou, L.; Ding, M.-W.; Yang, J.-Y.; Yang, S.; Xiao, W.-J. Bioorg. Med. Chem. Lett. 2009, 19, 3938.

4. Chen, J.; Sun, X.-Y.; Chai, K.-Y.; Lee, J.-S.; Song, M.-S.; Quana, Z.-S. Bioorg. Med. Chem. 2007, 15, 6775.

5. Küçükgüzel, İ.; Tatar, E.; Küçükgü̈zel, Ş. G.; Rollas, S.; De Clercq, E. Eur. J. Med. Chem. 2008, 43, 381.

6. Micheli, F.; Bonanomi, G.; Blaney, F. E.; Braggio, S.; Capelli, A. M.; Checchia, A.; Curcuruto, O.; Damiani, F.; Fabio, R. D.; Donati, D.; Gentile, G.; Gribble, A.; Hamprecht, D.; Ted esco, G.; Terreni, S.; Tarsi, L.; Lightfoot, A.; Stemp, G.; MacDonald, G.; Smith, A.; Pecoraro, M.; Petrone, M.; Perini, O.; Jacqui, P.; Rossi, T.; Worby, A.; Pilla, M.; Valerio, E.; Griffante, C.; Mugnaini, M.; Wood, M.; Scott, C.; Andreoli, M.; Lacroix, L.; Schwarz, A.; Gozzi, A.; Bifone, A.; Ashby, C. R., Jr.; Hagan, J. J.; Heidbreder, C. J. Med. Chem. 2007, 50, 5076.
7. Xiang, J.; Wan, Z.-K.; Li, H.-Q.; Ipek, M.; Binnun, E.; Nunez, J.; Chen, L.; McKew, J. C.; Mansour, T. S.; Xu, X.; Suri, V.; Tam, M.; Xing, Y.; Li, X.-P.; Hahm, S.; Tobin, Js.; Saiah, E. J. Med. Chem. 2008, 51, 4068.

8. Ahmad, S.; Madsen, C. S.; Stein, P. D.; Janovitz, E.; Huang, C.; Ngu, K.; Bisaha, S.; Kennedy, L. J.; Chen, B.-C.; Zhao, R.-L.; Sitkoff, D.; Monshizadegan, H. J. Med. Chem. 2008, 51, 2722.

9. Garfunkle, J.; Ezzili, C.; Rayl, T. J.; Hochstatter, D.G.; Hwang, I.; Boger, D. L. J. Med. Chem. 2008, 51, 937.

10. De Pauw, B. E. Int. J. Antimicrob. Agents 2000, 16, 147.

11. Johnsonl, L. B.; Kauffman, C. A. Clin. Infect. Dis. 2003, 36, 630.

12. (a) Wan, K.; Zhou, C.-H. Chin. Pharm. J. 2010, (in press). (b) Cha, R.; Sobel, J. D. Expert. Rev. Anti-Infect. Ther. 2004, 2, 357.

13. (a) Liu, P.; Zhu, S.-L.; Li, P.; Xie, W.-J.; Jin, Y.-S.; Sun, Q.-Y.; Wu, Q.-Y.; Sun, P.; Zhang, Y.-J.; Yang, X.-H.; Jiang, Y.-Y.; Zhang, D.-Z. Bioorg. Med. Chem. Lett. 2008, 18, 3261. (b) Meerpoel, L.; Backx, L. J. J.; Van der Veken, L. J. E. ; Heeres, J. ; Corens, D.; De Groot, A.; Odds, F. C.; Van Gerven, F.; Woestenborghs, F. A. A.; Van Breda, A.; Oris, M. ; van Dorsselaer, P.; Willemsens, G. H. M.; Vermuyten, K. J. P.; Marichal, P. J. M. G.; Vanden Bossche, H. F.; Ausma, J.; Borgers, M. J. Med. Chem. 2005, 48, 2184. (c) La Regina, G.; D’Auria, F. D.; Tafi, A.; Piscitelli, F.; Olla, S.; Caporuscio, F.; Nencioni, L.; Cirilli, R.; La Torre, F.; De Melo, N. R.; Kelly, S. L.; Lamb, D. C.; Artico, M.; Botta, M.; Palamara, A. T.; Silvestri, R. J. Med. Chem. 2008, 51, 3841.

14. (a) Zhou, C.-H.; Gan, L.-L.; Zhang, Y.-Y.; Zhang, F.-F.; Wang, G.-Z.; Jin, L.; Geng, R.-X. Sci. China. Ser. B-Chem. 2009, 52, 415. (b) Zhou, C.-H.; Zhang, F.-F.; Gan, L.-L.; Zhang, Y.-Y.; Geng, R. -X. Sci. China Ser. B-Chem. 2009, 39, 208 (in Chinese).

15. Luo, Y.; Lu, Y.-H.; Gan, L.-L.; Zhou, C.-H.; Wu, J.; Geng, R.-X.; Zhang, Y.-Y. Arch. Pharm. Chem. Life Sci. 2009, 342, 386.

16. Zhang, F.-F.; Gan, L.-L.; Zhou, C.-H. Bioorg. Med. Chem. Lett. 2010, 20, 1881.

17. Mi, J.-L.; Zhou, C.-H.; Bai, X. Chin. J. Antibiot. 2007, 32, 587.

18. Mi, J.-L.; Wu, J.; Zhou, C.-H. West China J. Parm. Sci. 2008, 23, 84.

19. Mavrova, A. T.; Wesselinova, D.; Tsenov, Y. A.; Denkova, P. Eur. J. Med. Chem. 2009, 44, 63.

20. Salgın-Gökşen, U.; Gökhan-Kelekçi, N.; Özgür, G.; Köysal, Y.; Kılıç, E.; Işık, Ş.; MeralÖzalp, G. A. Bioorg. Med. Chem. 2007, 15, 5738.

21. Bayrak, H.; Demirbas, A.; Karaoglu, S. A.; Demirbas, N. Eur. J. Med. Chem. 2009, 44, 1057.

22. Sato, T.; Ashizawa, N.; Iwanaga, T.; Nakamura, H.; Matsumoto, K.; Inoue, T.; Nagata, O. Bioorg. Med. Chem. Lett. 2009, 19, 184.

23. Navidpour, L.; Shafaroodi, H.; Abdi, K.; Amini, M.; Ghahremani, M. H.; Dehpour, A. R.; Shafiee, A. Bioorg. Med. Chem. 2006, 14, 2507.

24. Kuş, C.; Ayhan-Kılcıgil, G.; Özbey, S.; Kaynak, F. B.; Kaya, M.; Can-Eke, T. Ć. B. Bioorg. Med. Chem. 2008, 16, 4294.

25. Turan-Zitouni, G.; Kaplancıkl1, Z.; TahaYıldız, M.; Chevallet, P.; Kaya, D. Eur. J. Med. Chem. 2005, 40, 607.

26. Khanmohammadi, H.; Abnosi, M. H.; Hosseinzadeha, A.; Erfantalab, M. Spectrochimica Acta Part A 2008, 71, 1474.

27. Lin, R.-H.; Connolly, P. J.; Huang, S.; Wetter, S. K.; Lu,Y.-H.; Murray, W. V.; Emanuel, S. L.; Gruninger, R. H.; Fuentes-Pesquera, A. R.; Rugg, C. A.; Middleton, S. A.; Jolliffe, L. K. J. Med. Chem. 2005, 48, 4208.

28. Karegoudar, P.; Prasad, D. J.; Ashok, M.; Mahalinga, M.; Poojary, B.; Holla, B. S. Eur. J. Med. Chem. 2008, 43, 808.

29. Karthikeyan, M. S.; Holla, B. S.; Kumari, N. S. Eur. J. Med. Chem. 2008, 43, 309.

30. Kagoshima, Y.; Konosu, T. J. Fluorine Chem. 2006, 127, 643.

31. (a) Suzuki, T.; Moriya, M.; Sakamoto, T.; Suga, T.; Kishino, H.; Takahashi, H.; Ishikawa, M.; Nagai, K.; Imai, Y.; Sekino, E.; Ito, M.; Iwaas, H.; Ishihara, A.; Tokita, S.; Kanatani, A.; Sato, N.; Fukami, T. Bioorg. Med. Chem. Lett. 2009, 19, 3072. (b) Jadhav, G. R.; Shaikh, M. U.; Kale, R. P.; Shiradkar, M. R.; Gill, C. H. Eur. J. Med. Chem. 2009, 44, 2930. 
32. Chai, X.-Y.; Zhang, J.; Song, Y.-L.; Hu, H.-G.; Zou, Y.; Zhao, Q. -J.; Dan, Z.-G.; Zhang, D.-Z.; Wu, Q.-Y. Bioorg. Med. Chem. Lett. 2009, 19, 1811 .

33. Sheng, C.-Q.; Zhang, W.-N.; Ji, H.-T.; Zhang, M.; Song, Y.-L.; Xu, H.; Zhu, J.; Miao, Z.-Y.; Jiang, Q.-F.; Yao, J.-Z.; Zhou, Y.-J.; Zhu, J.; Lü, J.-G. J. Med. Chem. 2006, 49, 2512.

34. Rezaei, Z.; Khabnadideh, S.; Pakshir, K.; Hossaini, Z.; Amiri, F.;
Assadpour, E. Eur. J. Med. Chem. 2009, 44, 3064.

35. Koeh, M.; Pstein, E. P.; Stahler, G.; Main, F. US Patent 4467098, 1984.

36. (a) Kadi, A. A.; El-Brollosy, N. R.; Al-Deeb, O. A.; Habib, E. E.; Ibrahim, T. M.; El-Emam, A. A. Eur. J. Med. Chem. 2007, 42, 235. (b) Özbek, N.; Katırcıŏglu, H.; Karacan, N.; Baykal, T. Bioorg. Med. Chem. 2007, 15, 5105. 